\title{
M-learning: Connecting Teaching and Learning Inside and Outside of School
}

M-learning: conectando enseñanza y aprendizaje dentro y fuera de la escuela

Review paper | Artículo de revisión

Received on: February 21st 2019

Accepted on: July 1 st 2020

Available online from: July 2021

doi: 10.11144/Javeriana.m14.mlct

AndRÉs ChIAPPE-LAVERDE

andres.chiappe@unisabana.edu.co

Universidad de La Sabana, Colombia

ORCID: https://orcid.org/0000-0002-9664-4833

Gustavo Adolfo Paz-Balanta

gustavo.paz@correo.policia.gov.co

Universidad de La Sabana, Colombia

(D) ORCID: https://orcid.org/0000-0001-7642-8378

To cite this article | Para citar este artículo

Chiappe-Laverde, A. \& Paz-Balanta, G. A. (2021). M-learning: Connecting teaching and learning inside and outside of school. magis, Revista Internacional de

Investigación en Educación, 14, 1-24. doi: 10.11144/Javeriana.m14.mlct 


\section{Abstract}

The educational use of mobile devices, known as m-learning, is currently an alternative with great potential to address the crisis of the relevance of education as a social mechanism of the 21 st century. To address this issue, a systematic literature review on m-learning was conducted, from which it was found that, depending on the use given to mobile devices, at least three types of learning experiences are generated. Additionally, we identified the main advantages of m-learning, its risks, fields of application, and current research focuses.

\section{Keywords}

Computer assisted instruction; educational technology; m-learning

\section{Resumen}

El uso educativo de dispositivos móviles, conocido como m-learning, se presenta en la actualidad como una alternativa con gran potencial para abordar la crisis de pertinencia de la educación como mecanismo social de desarrollo en el siglo XXI. Para abordar este asunto, se condujo una revisión sistemática de literatura sobre m-learning, a partir de la cual se encontró que, dependiendo del uso dado a los dispositivos móviles se generan al menos tres tipos de experiencias de aprendizaje de naturaleza distinta. Adicionalmente, se identificaron las principales ventajas del m-learning, sus riesgos, ámbitos de aplicación y focos actuales de investigación.

\section{Palabras clave}

Enseñanza informatizada; tecnología educacional; aprendizaje móvil 
Article description | Descripción del artículo

Review paper derived from the project Teaching Mediated

by Learning Objects for Mobile Devices: What about

Didactic Transposition?

\section{Introduction}

Currently, education is being criticized from different sectors, due to the relevance of its way of operating, its structure and paradigms (Carnie, 2017; Prensky, 2008; Seyedmonir, 2013). From basic educational level to higher education, the continuity of a homogenizing and industrial-type system is being questioned (Huber, 2013; Punset, 2011; Robinson, 2017), which operates on the basis of complying with standards to which all students must aim (Liss, 2013), and that has little contribution to the development of students' individual talents and skills required by the rapidly changing context of the 21st century (Romero et al., 2015).

Latin American educational systems focus almost exclusively on what is planned to happen and what happens inside the classrooms, largely ignoring or dismissing the learning that happens outside of school, which can become very powerful and relevant to each person, precisely because of its contextualized and situated nature (Bell et al., 2013).

On the other hand, not only current education is being looked at carefully, also the processes of incorporating technologies into education. These processes, since their inception, were promoted under great expectations of educational improvement and transformation (Collins \& Halverson, 2010). However, current school's realities reveal that technology is far from its fulfillment or satisfaction. This is evidenced not only from very low indicators of ICT educational integration, especially in public basic education (Sunkel, 2006), but also from the predominance of teaching strategies based on direct instruction or teacher-centered pedagogies (Hervis, 2017).

There are various technologies (analog and digital) that have been developed and brought into educational processes for more than seven decades. For instance, radio and television stand out from analog technologies. Among others, personal computers, CD-ROMs, smartboards, information networks (Internet) and mobile devices stand out from digital technologies. Much research has been done on its effectiveness, convenience and limitations (Juneau, 2012; Wegerif \& Major, 2018), with contrary perspectives. That is, favorable studies highlight the benefits as educational mediators and enhancers of flexible and collaborative learning 
(Zempoalteca-Durán et al., 2017), yet unfavorable studies point out their risks and inconveniences as distractors and generators of social isolation (Muñoz-Miralles et al., 2014).

Figure 1 shows that for just over twenty years, digital technologies have focused mostly on the use of internet, either supporting remote and distributed processes, commonly called e-learning (A. W. Bates, 2015), as complement to face-to-face educational processes or blended learning (Horn \& Fisher, 2017), or as processes associated with the use of mobile devices, which is known as m-learning (Pedro et al., 2018).

Figure 1

Growth of research on internet use in education (Scopus)

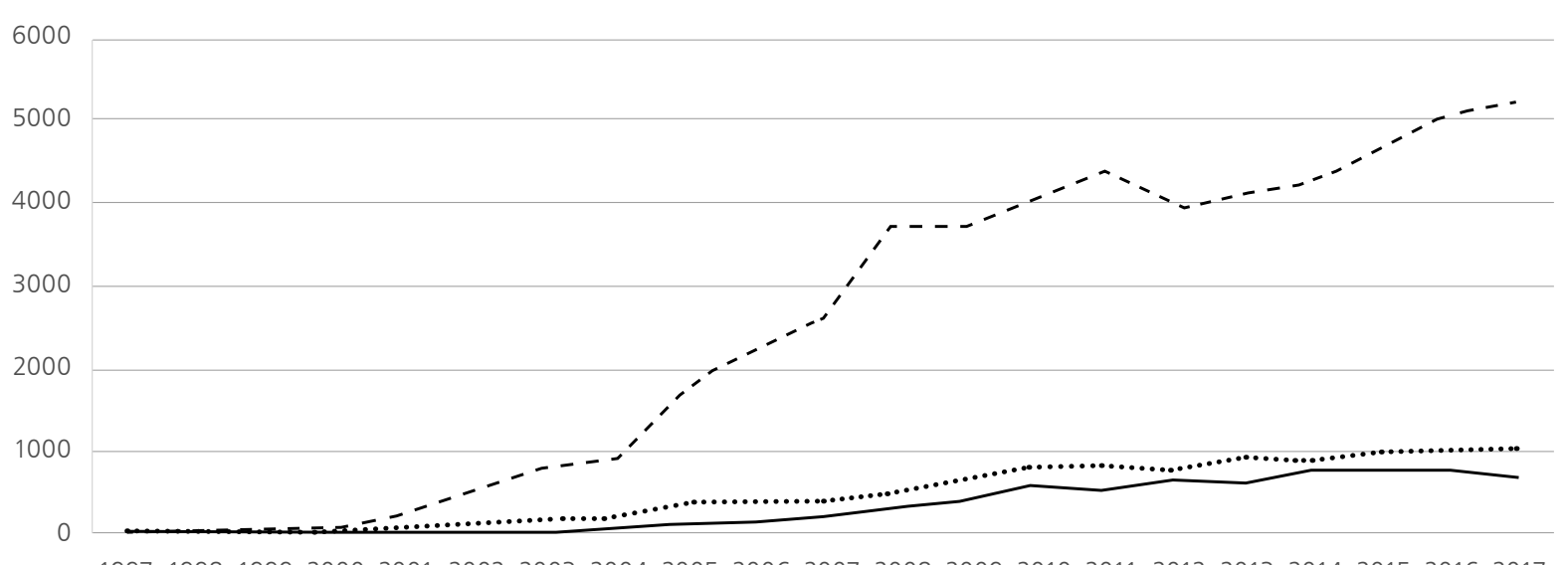

199719981999200020012002200320042005200620072008200920102011201220132014201520162017

— M-learning - - E-learning $\quad \cdots . .$. B-learning

Source: Own source from Scopus data

In its beginnings, mobile learning or m-learning, from an eminently technology-centered perspective, was conceived as the mere use of portable electronic devices for behavior modification (Kukulska-Hulme \& Traxler, 2005). However, a more recent perspective reveals characteristics more related to learning in mobility contexts, such as flexibility, personalization, diversity and ubiquity. The latter understood not as the possibility of being in several places at the same time (as it could be suggested by an e-learning type process) but about the possibility of actively participating in learning, anywhere and at any time, giving rise to the term anytimeanywhere, as the characteristic slogan of m-learning (Cárdenas-Robledo \& Peña-Ayala, 2018).

Authors such as Rienzo (2014), Casagranda et al. (2011), Vanbaelen et al. (2014) mention that learning is not only generated in the moments in which one is in a classroom and with the mediation of a teacher. In fact, 
human beings cannot give up on learning, since this is human's most intimate nature and is done all the time, from birth to death (Vidmar, 2014).

Accordingly, if the student moves daily along different social contexts (family, school, community, etc.) and brings any mobile technology, it will help the student to take advantage of the different contexts where the student learns and will contribute to generate changes in the learning experiences themselves. Unlike the offer of predetermined content and homogenized learning experiences that the formal education system could offer, the possibility of taking advantage of what the real context offers as learning inputs greatly increases the relevance of what is learned.

In this regard, the Organización de las Naciones Unidas para la Educación, la Ciencia y la Cultura (Unesco) (2013) indicates:

Mobile learning involves the use of mobile technology, either alone or in combination with other information and communication technologies (ICT), to enable learning anytime and anywhere. Learning can take place in a number of ways: People can use mobile devices to access educational resources, connect with others, or create content, both inside and outside the classroom. Mobile learning also accompanies efforts to support broad educational goals, such as effective administration of school systems and better communication between schools and families (p. 6).

Based on the above, it is possible to recognize the potential of m-learning to articulate learning spaces, inside and outside of school and on an ongoing basis, which also suggests its relevance as a factor for strengthening lifelong learning. It is worth mentioning the importance of this issue in the framework of the development of human talent for the 21st century (Van Laar et al., 2017), especially when the current global context is highly changing, as well as where people are forced to rethink and transform their professional profile several times throughout their lives (Blaschke, 2012).

Now, under the understanding that m-learning provides diverse learning experiences adjusted to a continuous and daily personal mobility and, on the other hand, recognizing its growth as an object of research and practical experiences at various educational levels, it is valid to ask ourselves: how much do we currently know about its contributions to teaching and learning inside and outside the classroom?

To address this question, a systematic literature review on m-learning has been carried out in order to identify, based on research published in the last 20 years, the educational uses of mobile devices, understood as smartphones or tablets and in particular the advantages and limitations of their use, the educational levels in which they have been applied and the focus of their current discussion within the framework of educational research. 


\section{Method}

The literature review was conducted following the guidelines of Okoli \& Schabram (2010) through the following phases, which are summarized in figure 2 .

Figure 2

Phases of the review

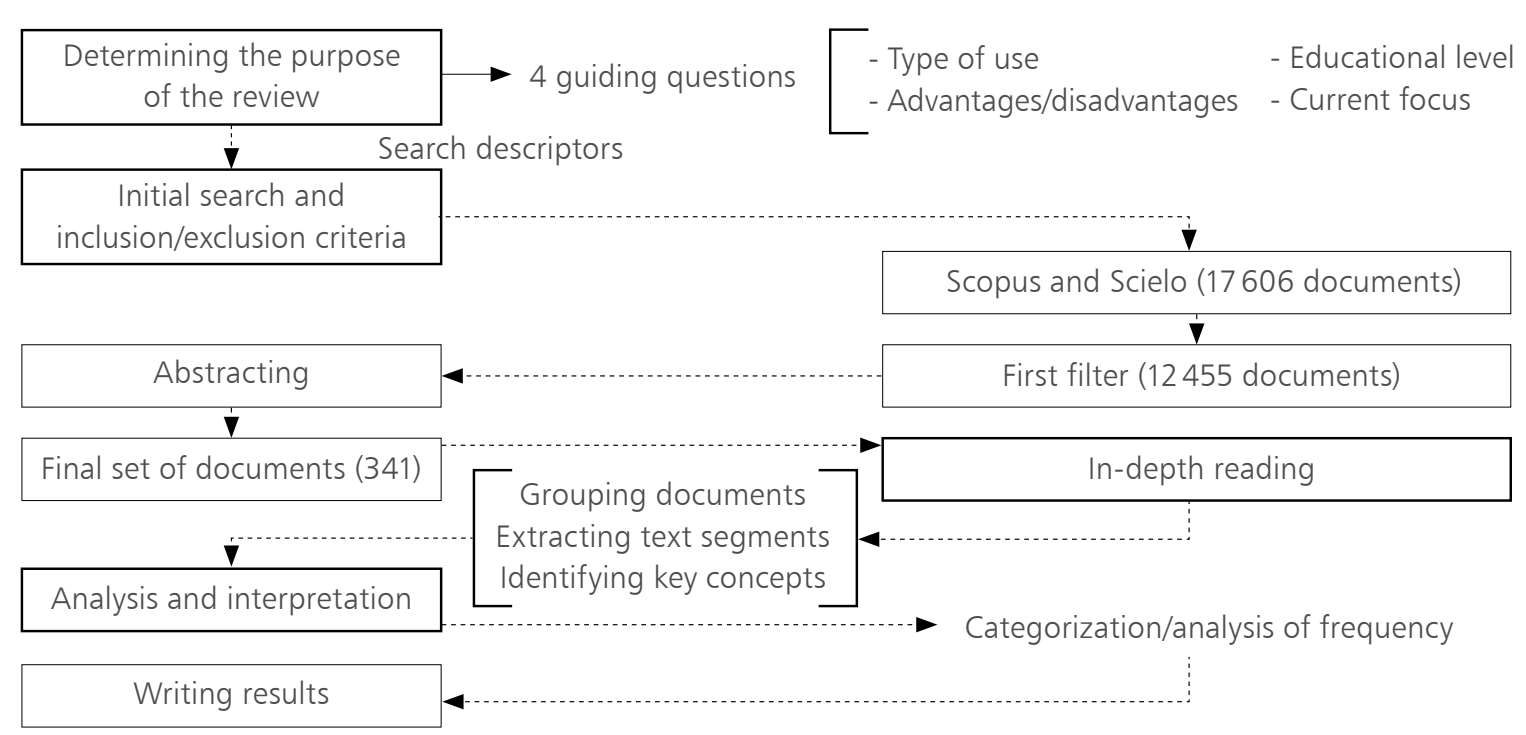

Source: Own source from Okoli \& Schabram (2010)

\section{Purpose of the Review}

The purpose stated above, at the end of the previous section, was consolidated from the formulation of four guiding questions: What have been the main uses of mobile devices in education? What advantages or difficulties can be highlighted from its educational use? At what educational levels have they been applied most frequently? And what is the current focus of m-learning research? To address these questions, the following search descriptors were defined: ALL (m-learning OR "mobile learning"), which were applied to two of the main journal databases arbitrated and of high impact: Scopus and Scielo. The choice of these databases ensured a wide coverage of high quality publications in both English and Spanish/Portuguese.

The next step in this first phase consisted on determining criteria for inclusion or exclusion of articles. These criteria established that:

- Only articles with research results were selected.

- Articles in English and Spanish were reviewed in proportion to the annual production reported in the databases. 
- The time frame for circumscribing the review contemplated the last 20 years (1999-2018). The review was focused on the first years of the massification of the internet and mobile phones.

\section{Initial Search of the Literature and Application of Inclusion and Exclusion Criteria}

Search descriptors showed a general set of 17606 documents; accordingly, a filtering search was applied by subject area (social sciences and computer sciences) and by type of document. Then, we selected the documents published in the last 20 years (1999-2018) in both English and Spanish. After such filtering, we compiled a set of 16036 documents.

\section{Abstracting and Filtering}

Due to the fact that the number of publications in English and Spanish, as well as those found in Scopus and Scielo, were high in volume and, at the same time, so dissimilar (figure 3), it was decided to calculate a representative sample with a confidence level of $\underset{z^{2} \times p(1-p)}{95 \%}$ and a margin of error of $5 \%$ from the following equation: $m=\frac{z^{2} \times p(1-p)}{1+e^{z^{2} \times p(1-p)} \times e^{2} N}$, with which we estimated a second set of documents $(n=376)$ to then advance in the next process called "abstracting". We read the titles and abstracts of the selected texts to determine and ensure its thematic relevance (correspondence of the article with the educational use of mobile devices) and the presentation of research results within the texts. This process complemented the first filtering on the databases.

Figure 3

Publications on m-learning in Scopus and Scielo

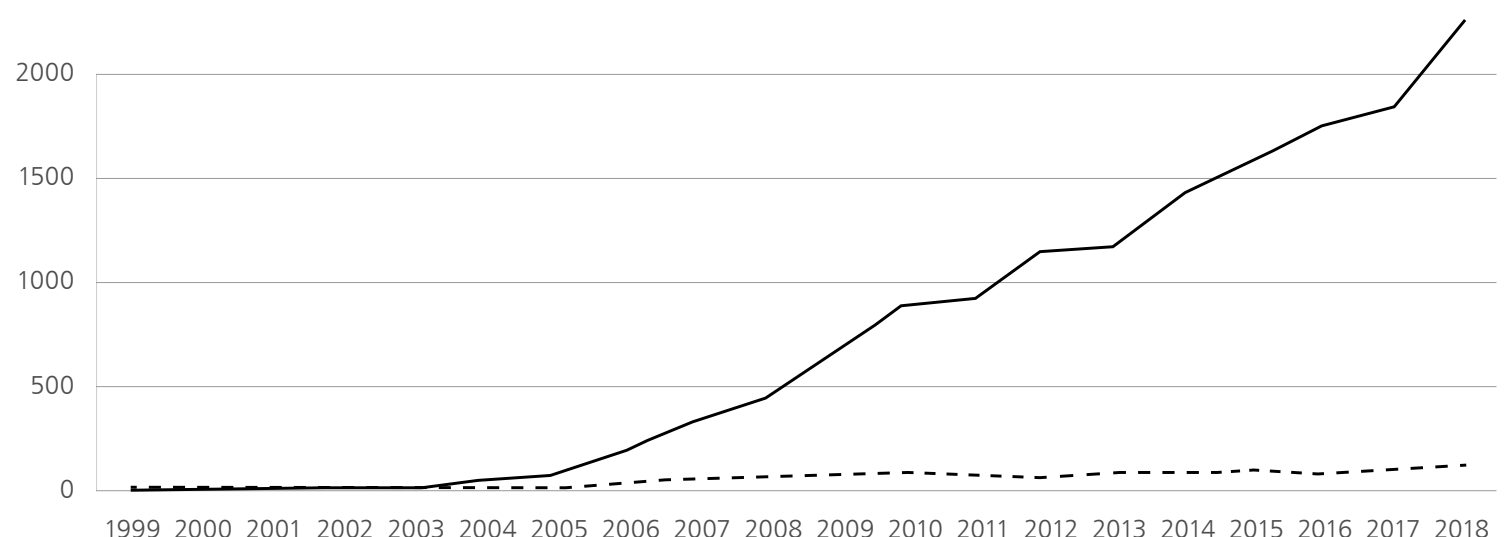

— M-learning (Scopus) - - - E-learning (Scielo) 
On the other hand, this number proportionally reflected the high volume of publications of both databases, for which it was decided to make a weighted selection by year and language to configure a final set of documents.

Table 1 shows the final result of the abstracting and weighting process of the publications in both databases. A set of 341 documents was finally decided (35 documents were eliminated due to relevance issues) to start the reading process in deep.

Table 1

Final set of documents for in-depth reading

\begin{tabular}{c|c|c|c|c|c}
\hline Year & Scopus & Scielo & Year & Scopus & Scielo \\
\hline 2018 & 32 & 4 & 2008 & 12 & 1 \\
\hline 2017 & 27 & 3 & 2007 & 9 & 1 \\
\hline 2016 & 30 & 4 & 2006 & 6 & 1 \\
\hline 2015 & 30 & 4 & 2005 & 9 & 1 \\
\hline 2014 & 27 & 4 & 2004 & 2 & 1 \\
\hline 2013 & 25 & 3 & 2003 & 1 & 1 \\
\hline 2012 & 25 & 3 & 2002 & 1 & 1 \\
\hline 2011 & 21 & 3 & 2001 & 1 & 1 \\
\hline 2010 & 22 & 3 & 2000 & 1 & 1 \\
\hline 2009 & 16 & 2 & 1999 & 1 & 1 \\
\hline
\end{tabular}

Source: Own source based on data from Scopus and Scielo

\section{Deep Reading and Data Extraction}

The in-depth reading was done in parallel with the data extraction based on the guiding questions that were posed at the beginning of the review. For this purpose, a data matrix was generated, including the references of the selected articles, the type of mobile use indicated in each study, the advantages and disadvantages and the educational level in which each study was carried out.

\section{Analysis and Interpretation}

Data in the analysis matrix was analyzed qualitatively through a process of categorization by familiarization. In this process, common elements were identified from the literature, which were classified around differentiated patterns based on relationships between them. To do such classification, a process of unification and homologation of terms was previously carried out to finally proceed with a process of frequency analysis of the constituent terms of each category.

In order to ensure consistency in the process of recording and analyzing the information recorded in the data matrix, a triangulation was carried out by two observers, in order to reduce bias. For this purpose, each observer 
verified the correspondence between the data extracted and the source from which they were taken, which was recorded independently and compared.

The reliability of this observation process was addressed by doing a Cohen's Kappa coefficient $(k)$ as an inter-rater measurement instrument, through the following equation: $k=\frac{\operatorname{Pr}(a)-\operatorname{Pr}(e)}{1-\operatorname{Pr}(e)}$, which was $k=0.516$. This result took into account the concordances and disparities in the observations that each observer recorded in the data matrix. According to Bendermacher \& Souren (2009), this result indicates an acceptable level of reliability for this type of process.

\section{Writing Results}

As a final process, data was interpreted and translated into a literature review based on the guiding questions asked at the beginning of the review.

\section{Results}

The 341 articles reviewed were distributed heterogeneously in 53 high impact journals in the categories "Social Sciences" and "Computer Sciences" in SJR. Table 2 shows the top 10 (percentages) of articles reviewed for indepth reading by journal and the percentage of participation of each journal in the total number of articles indexed in Scopus on this topic. In addition, the quality of the sources consulted is indicated in terms of their impact factor based on the measurements of the Scientific Journal Rankings (SJR) and the Journal Citation Reports (JCR) and their location in the SJR quartiles.

Table 2

Top 10 journals consulted-quality of the reviewed sources

\begin{tabular}{|c|c|c|c|c|c|c|c|}
\hline Journal & ISSN & \begin{tabular}{|c|} 
Total \\
Percentage
\end{tabular} & $\begin{array}{c}\text { Percentage } \\
\text { read }\end{array}$ & ImpF-SJR & $\begin{array}{l}\text { Quartil } \\
\text { SJR }\end{array}$ & ImpF-JCR & $\begin{array}{l}\text { Quartil } \\
\text { JCR }\end{array}$ \\
\hline Computers and Education & $0360-1315$ & $1.9 \%$ & $5.71 \%$ & 2.63 & Q1 & 4.53 & Q1 \\
\hline Lecture Notes in Computer Science & $0302-9743$ & $4.7 \%$ & $4.29 \%$ & 0.29 & Q2 & 0.4 & Q4 \\
\hline $\begin{array}{l}\text { International Journal of Mobile } \\
\text { Learning and Organisation }\end{array}$ & $1746-725 X$ & $1.5 \%$ & $4.29 \%$ & 0.85 & Q1 & $-\cdots$ & $-\cdots$ \\
\hline $\begin{array}{l}\text { Revista Iberoamericana de } \\
\text { Tecnologías del Aprendizaje }\end{array}$ & $1932-8540$ & $0.2 \%$ & $4.29 \%$ & 0.26 & Q2 & --- & --- \\
\hline $\begin{array}{l}\text { British Journal of Educational } \\
\text { Technology }\end{array}$ & $1467-8535$ & $0.9 \%$ & $2.86 \%$ & 1.34 & Q1 & 2.72 & Q1 \\
\hline $\begin{array}{l}\text { Education and Information } \\
\text { Technologies }\end{array}$ & $1360-2357$ & $0.4 \%$ & $2.86 \%$ & 0.4 & Q2 & $-\cdots$ & $-\cdots$ \\
\hline $\begin{array}{l}\text { International Journal of Educational } \\
\text { Technology in Higher Education }\end{array}$ & $2365-9440$ & $0.1 \%$ & $2.86 \%$ & 0.39 & Q2 & --- & --- \\
\hline Journal of Computer Assisted Learning & $1365-2729$ & $0.5 \%$ & $2.86 \%$ & 1.4 & Q1 & 1.85 & Q1 \\
\hline $\begin{array}{l}\text { International Review of Research in } \\
\text { Open and Distance Learning }\end{array}$ & $1492-3831$ & $0.6 \%$ & $1.43 \%$ & 1.26 & Q1 & 1.82 & Q2 \\
\hline Interactive Learning Environments & $1049-4820$ & $0.6 \%$ & $1.43 \%$ & 0.66 & Q1 & 1.6 & Q2 \\
\hline
\end{tabular}




\section{Educational Use of Mobile Devices}

Of the studies reviewed, 254 (58.9\%) indicated the way in which mobile devices were used in the framework of a learning environment. After categorizing the data, we found three types of use of mobile devices, which referred to three very different types of learning experiences: 1) the most frequent $(66.1 \%, \mathrm{n}=168)$ refers to the use of the mobile device as a means of distribution or access to content outside the classroom; 2) the second one $(21.3 \%, n=54)$ refers to the use of mobile phones to create content, or as part of experiential, situated and highly contextualized learning strategies and 3) the least frequent $(12.6 \%, n=32)$, reported the use of mobile phones within the classroom to generate enriched interactions, either between students or with the content, and to promote changes in motivational dynamics.

\section{The Mobile Device as a Content Distribution Channel}

In this category, we included studies that referred to the slogan with which m-learning processes are most commonly identified: Learning "anytime-anywhere" or ubiquitously. These processes are generally situated either in a formal context involving school dropout or independent work outside of school $(90.7 \%, n=49)$ or in the field of adult or corporate learning, commonly known as vocational learning or "for work" $(9.3 \%, n=5)$. This way of using the mobile device offers a learning experience in which the moments of "unproductive leisure" are used (Organero et al., 2009), including the spaces that are not traditionally identified as "spaces to learn", such as waiting rooms, long journeys in public transport systems or places of temporary rest. These places become spaces where the student, almost always alone, has the possibility of accessing educational content designed to be reviewed through the phone or a tablet (Tosi \& Bisiani, 2007). Other examples can be found in: Murphy et al. (2014), Trifonova \& Ronchetti (2006), Shippee \& Keengwe (2014), Willemse et al. (2019) and Nikou \& Economides (2018).

The link between this type of use of a mobile device with teaching, inside and outside of school, is within the framework of independent work, either as a preparation mechanism before class or as a reinforcement or complement outside the classroom.

\section{The Mobile Device as a Tool for Creating Content on Site}

The second type of educational use of mobile devices has to do with taking advantage of their technical and connectivity functionalities at the service of situated and experiential learning strategies (Waliński, 2014). In these types of experiences, the student leaves the classroom, and sometimes 
the school, to learn "where things happen". For this purpose, strategies are activated in which students use their mobiles to document their observations, record and share information captured directly in the context in which they are (Huang et al., 2012 ; Zurita \& Baloian, 2012). In many cases, the experiences documented by students through their phones are taken to the classroom to link them to other processes of socialization and collaborative reflection (Comas-Quinn et al., 2009). Other examples can be found in: Slotta et al. (2018), Fatima et al. (2019), Melles et al. (2019) or Chen \& Hwang (2017).

This type of use of a mobile device best establishes a channel for articulating teaching inside and outside of school. However, it is a rare type of learning experience when referring to m-learning. ies of the classroom, uses the device's own mobility to generate enriched processes for approaching content (each student can do it in a different way. It is flexible in time and frequency). On the other hand, through the use of augmented reality applications, there is an interesting possibility to revitalize the printed contents used in class and to increase student's depth and interest in them, given the ability to link different contents in various formats through interactive links (Bulagang \& Baharum, 2019; Efstathiou et al., 2018; Kurubacak \& Altinpulluk, 2017). This type of use of mobile devices has a wide practical application but does not favor the articulation of teaching inside and outside the school, since it focuses on the enrichment of content and interactions within the classroom, but not on those that could happen out of it.

\section{Advantages and Disadvantages of Using Mobile Phones in Education}

The analysis and categorization of the reviewed data showed a great diversity in terms of advantages of the application of mobile devices in teaching and learning processes, as shown in figure 4. 
Figure 4

Advantages of using mobile devices

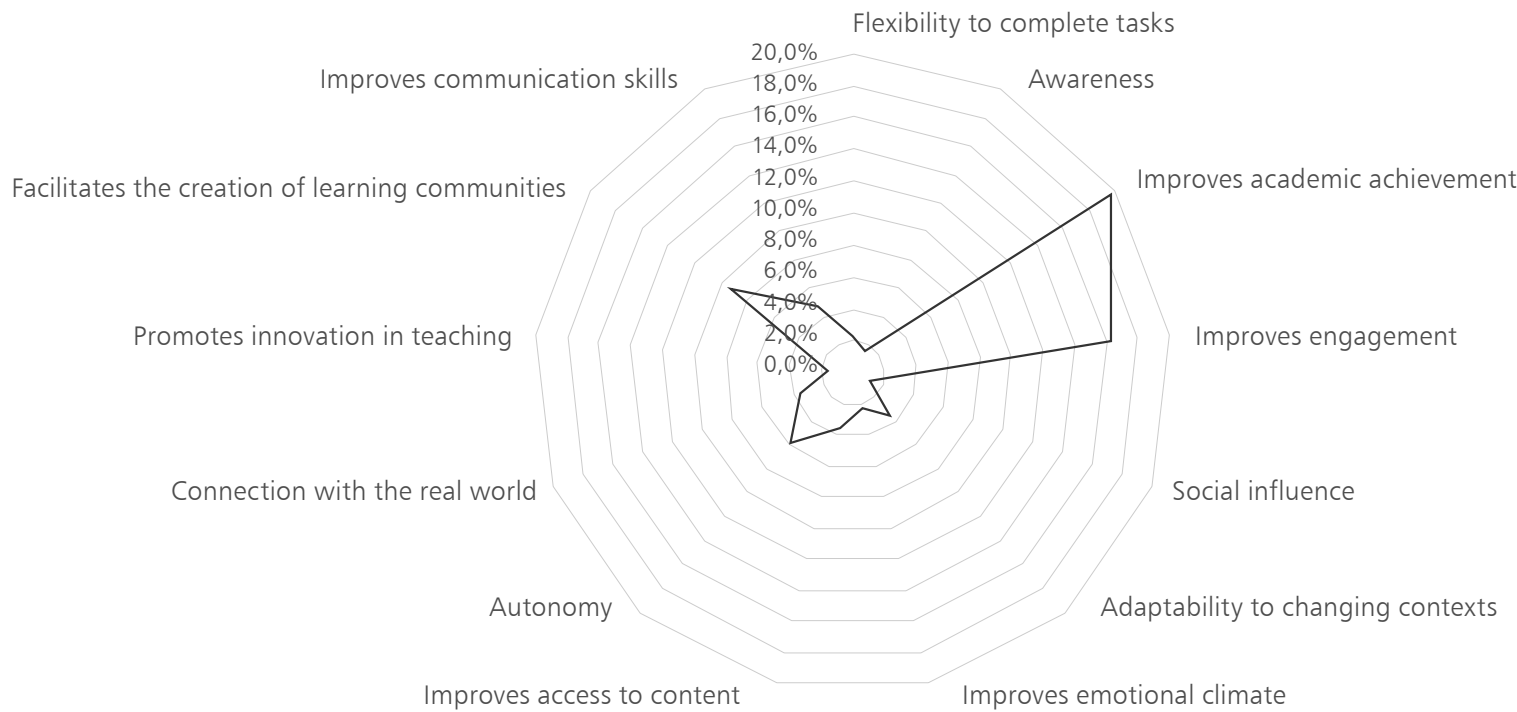

Source: Own source

Results show, in a general way, a positive perspective of the use of mobile devices in educational processes, which contrasts with public's general opinion, including school authorities, who usually point out to their risks as one of the current major learning distractors in classrooms (Rodríguez, 2013). Although $26.7 \%(n=115)$ of the studies did not focus on highlighting advantages or risks in the use of mobile devices to teach or learn, from the remaining set of articles, only $11.4 \%$ of the studies reviewed $(n=49)$ mentioned the disadvantages or risks of implementing mobile devices in education. On the other hand, $88.4 \%(n=381)$ of the studies showed at least one advantage or potentially interesting issue for the improvement of some aspect, either for teaching or for learning, among which we highlight: Academic performance improvement (19.7\%; $n=75$ ) particularly regarding knowledge appropriation and outcomes in evaluation (Chang et al., 2018; Chou \& Feng, 2019), the strengthening of school engagement $(16.3 \% ; n=62)$, the potential to facilitate the creation of learning communities $(9.2 \% ; n=35)$, especially regarding the possibility and ease of sharing content or performing collaborative activities in real time and the strengthening of students' autonomy $(5.8 \% ; n=22)$, which is related to the increase in students' control over their learning pace and the flexibility to complete tasks.

In addition to the above, between $4.7 \%$ and $3.5 \%$ of the studies identified other advantages, for example, the improvement of communication 
skills, the connection of learning with the real world, the improvement of access to the contents and adaptation of the learning process to different contexts (Chen \& Hwang, 2017; Chung et al., 2019; Zaragoza et al., 2019). Finally, we found a set of advantages that did not appear very frequently $(1.2 \%$ to $2.3 \%)$, but which were recognized as relevant for the purposes of the review, namely: The flexibility to complete tasks, the improvement of the emotional climate and the use of social influence as a factor for teaching innovation. Examples can be found in: Wang et al. (2019), Pimmer et al. (2019) or Kaliisa \& Picard (2017).

In relation to the disadvantages or risks of the educational use of mobile devices, the main focuses were on: The pedagogical challenge in its implementation in traditional learning settings and the increase in the complexity of learning settings (Birt et al., 2018); the risk of students' multitasking, which hinders teacher's class facilitation (Pedro et al., 2018), stu-

dents' gaps, in terms of prior knowledge and skills, which are necessary for teachers' implementation (Shadiev et al., 2018); the existence of educational contexts with very limited computing capabilities, information storage and access to mobile bandwidth networks (Kalpana et al., 2018; Willemse et al., 2019) and students' precarious development of autonomy (Fatima et al., 2019).

\section{Educational Settings for Mobile Devices}

The use of mobile devices has been found in conjunction with other ICT integration scenarios, such as e-learning, MOOCs, inverted classes or mixed or blended learning processes, which indicates that one of the key characteristics of the use of mobile devices in education is to complement learning methods. Although it is possible to track cases in which teaching processes are conducted entirely using mobiles, their greatest impact is achieved when combining strategies with other technologies (Mallya \& Dhas, 2016; Muyinda, 2007; Şendurur et al., 2017).

In addition, four different fields or contexts of application were recognized, three of them in the framework of formal education and one located in non-formal education. The most frequent was found in Higher Education (56.8\%; $n=245$ ), where its use was primarily focused on the use of specific apps or measurement or calculation instruments that are part of mobile devices. Then, in primary and secondary education (23.9\%; $n=103)$, where mobile phones are used as channels to deploy gamification or learning strategies through games, and as a factor to improve engagement and motivation in general. The third area, according to the frequency of appearance, is pre-school ( $1.2 \% ; n=5)$, where the use of mobile devices is mainly limited to the classroom borders through the use of educational games and 
for the development of fine motor skills and hand-eye coordination. On the other hand, in non-formal education, such as vocational or corporate education (18.1\%; $n=78$ ), the use of mobile phones is adapted to the current characteristics of professional interactions and the needs of a good part of the people who go through learning processes or corporate training, who have little time available for face-to-face training processes and work at considerable distances from their homes.

\section{Current Research on M-learning}

In order to identify current research on the use of mobile devices, we filtered the studies published with the highest citation in the period between 2016 and 2018 (66.1\%; n = 285), where 13 issues were identified as main research interests, which are shown in figure 5.

Figure 5

Current research on the use of mobile devices in education (m-learning)

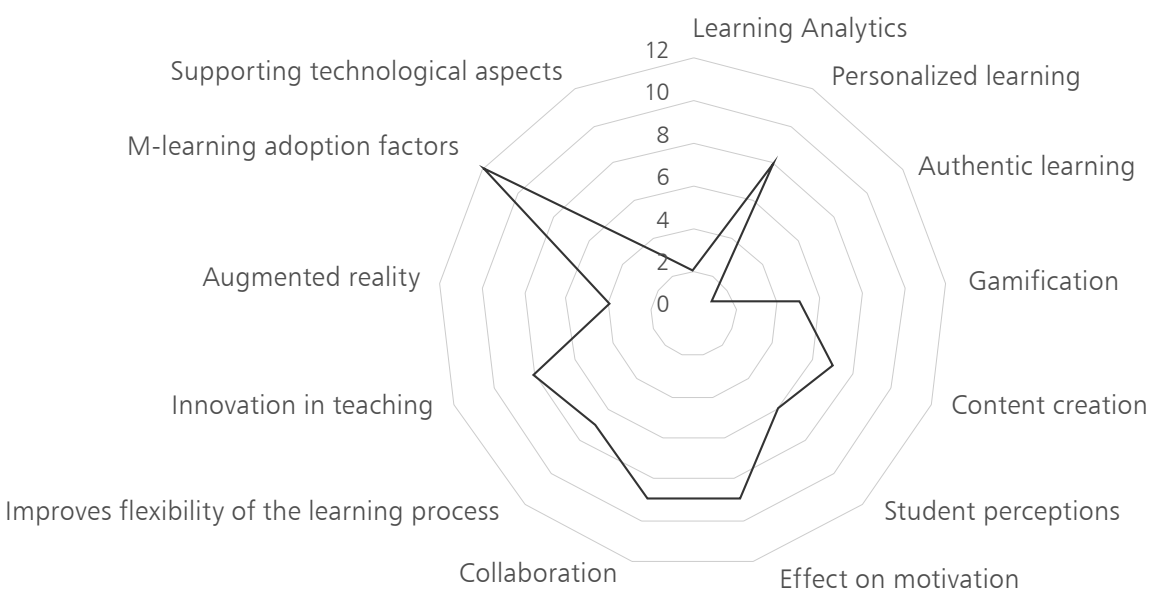

Source: Own source

Results show that the current discussion on the subject is diverse and, although some aspects addressed in previous literature reviews on this subject are taken up again (Fetaji \& Fetaji, 2011; Hussain et al., 2015; Toh et al., 2015), new topics are more decisively involved, which in previous years barely appeared as emerging, such as gamification, the use of augmented reality and learning analytics. Accordingly, the most frequent research focus corresponds to studies carried out with the purpose of identifying the most relevant factors of $m$-learning $(21.4 \% ; n=61)$. Also, there are two equally frequent topics $(15.4 \% ; n=44)$ that correspond, on the one hand, to studies focused on determining the effect of the use of mobile devices 
on motivation and, on the other, to studies focused on collaborative work. In addition to the above, there are two other fairly frequent topics (12.3\%; $n=35)$ that are related to each other: M-learning as a factor for personalizing learning, and as a tool for promoting innovation processes in teaching. Also, $10.9 \%(n=31)$ of the sample refer to two topics that were widely discussed in the literature in previous years: The improvement of the flexibility of the learning process (anytime-anywhere) and the particular aspects regarding the processes of mobile educational content creation.

Finally, research with less frequency of appearance was identified; however, these papers were particularly interesting given the current ICT evolution. In this group we found the use of augmented reality for educational purposes (7.0\%; $n=20)$, learning analytics ( $4.6 \% ; n=13)$, gamification ( $8.8 \% ; n=25)$, students' perceptions regarding learning mediated by mobile devices (10.1\%; $n=29)$, technological aspects of support for mobile learning systems and strategies $(6.3 \% ; n=18)$ and authentic learning $(3.2 \% ; n=9)$.

\section{Discussion}

Many are the reflections that could be derived from the results found in this review. The first has to do with noticing certain issues related to the very concept of m-learning. Although none of the guiding questions in the review focused on the conceptual exploration of m-learning, the same review exercise allowed us to identify that some conceptual definitions are not precise. Accordingly, there are numerous publications that define m-learning as "e-learning with mobiles". However, the results of this review openly contradict such definition. If e-learning is conceived as T. Bates (2015) does, these learning processes would be clearly distributed (as distance processes) and entirely mediated by ICT. In this sense, as indicated by the results related to the types of use of mobile devices, m-learning processes can be used in conjunction with face-to-face classes, a flipped classroom and with other flexible ICT educational integration schemes, which places them far beyond the limits of e-learning.

On the other hand, m-learning is found as one of the most appropriate option to undertake teaching articulation processes inside and outside the classroom, due to its conditions of flexibility, personalization and different uses and contributions to the quality of students' learning experiences, which enables a more authentic approach to both the content and the context where the knowledge to be learned is produced.

In our current world, which changes rapidly and is characterized by growing ambiguity and uncertainty (Balgopal, 1993), learning mechanisms 
are needed to allow people to undertake "learning throughout life" processes. When, where and with the urgency with which they are needed.

Thus, the use of a personal electronic device, portable and permanently connected to information networks, would become the main source for the creation of a personal learning ecology throughout life, with an efficient link between formal and informal learning.

Related to the above, we find in m-learning an alternative to revise one of the great unfulfilled promises of "Educational Technology" from its initial formulations: The personalization of learning (Bartolomé et al., 2018), which is an appropriate complement to the projection of learning beyond the boundaries of the classroom.

Accordingly, adaptation and flexibility are factors that promote such personalization in both students and teachers, to the extent that it is possible to learn and teach at their own pace, with access to teaching materials potentially adjustable to their needs, interests and abilities; as well as being able to expand the learning environments beyond what a classroom can provide, both in time and space.

\section{Conclusions}

There are various recommendations for educational stakeholders related to m-learning that become challenges and opportunities for future research, accordingly to the results and reflections left by this study. We highlight the following recommendations:

It is considered of great importance to undertake processes that are quickly consolidated around the production of mobile educational content, through the generation of educational apps or similar resources that cover various topics and educational levels, and that could adapt to different educational contexts.

The use of mobile devices as instruments for the generation of situated, highly contextualized and experiential learning experiences that occur beyond the borders of the classroom, implies the urgency of designing multiple teaching strategies that take advantage of technical functionalities of these devices, as well as their potential for interaction based on their mobile nature.

This is a challenge of great complexity given the restrictions that teachers have when implementing teaching strategies that could distance themselves from the current regulations envisaged by the educational system, especially in public schools in primary and secondary education.

On the other hand, the use of mobile devices as a channel for promoting printed school content (for example, through augmented reality or QR codes), represents for publishers and other companies that create school 
content, a challenge and an opportunity to generate innovative educational content, mainly based on the convergence of media and digital educational environments.

It is worth mentioning that, in times when the convenience of using mobile devices in schools and colleges is being questioned, it is recommended that this issue be a part of institutional planning processes and agreement between the different levels of school life. In this way, it will be possible to make a convenient use of these technologies, which have great educational potential and may contribute to the much-needed educational updating and transformation processes that our times require.

In addition, we find another relevant issue for future areas of research: As one of the main focuses of interest of m-learning is related to the various factors of adopting the use of mobile devices in education, it would be convenient to explore the way to cross the barriers imposed by the ignorance of their pedagogical use and some public policies that restrict their use, so that both teachers and students end up recognizing these devices as a tool for teaching and learning. It was mentioned in this article that there is a certain aversion to their use in classrooms, since they are recognized as distractors and as factors of distancing and isolation from physical interactions. However, given the pedagogical possibilities identified in this study, it would also be advisable to rethink these policies in order to propose a more open and conscious scenario about their use as instruments and mediators for teaching and evaluating, in personalized and more flexible circumstances. Also, as a pertinent type of education in accordance with the demands of the 21 st century.

\section{Acknowledgment}

We would like to thank the University of La Sabana for the support provided for the development of the research and the writing of this article.

\section{About the authors}

Andrés Chiappe-Laverde is a tenured professor at Universidad de La Sabana, Colombia. Senior researcher and peer evaluator of Minciencias for research programs and projects on topics related to the use of ICT in Education. In addition, he is fellow of the Unesco/ICDE Chair on the Open Educational Movement for Latin America and founder of RIIITED.

Gustavo Adolfo Paz-Balanta is a Police Administrator of the National Directorate of Schools of the National Police of Colombia. He holds a certificate in Research and University Teaching from Universidad La Gran Colombia, 
Colombia. Also, he holds a certificate in Management of Continuing Education and Learning from Sergio Arboleda University, Colombia. In addition, he holds a certificate in Virtual Teaching and Curriculum Design by competencies. Master in Educational Informatics at the University of La Sabana, Colombia. Head of the teaching Area of Continuing and Distance Education of the International School of the Use of the Police Force for Peace (Cenop) and Officer of the National Police of the Republic of Colombia.

\section{References}

Balgopal, P. R. (1993). Preparing competent social workers for the 21st century. Asia Pacific Journal of Social Work and Development, 3(1), 7-13. https://doi. org/10.1080/21650993.1993.9755623

Bartolomé, A., Castañeda, L. \& Adell, J. (2018). Personalisation in educational technology: The absence of underlying pedagogies. International Journal of Educational Technology in Higher Education, 15(1). https://doi.org/10.1186/ s41239-018-0095-0

Bates, A. W. (2015). Teaching in a digital age. http://dergipark.gov.tr/download/ article-file/81627

Bates, T. (2015). Teaching in a digital age: Guidelines for designing teaching and learning for a digital age. https://pressbooks.bccampus.ca/teachinginadig italagev2/

Bell, R. L., Maeng, J. L. \& Binns, I. C. (2013). Learning in context: Technology integration in a teacher preparation program informed by situated learning theory. Journal of Research in Science Teaching, 50(3), 348-379. https:// doi.org/10.1002/tea.21075

Bendermacher, N. \& Souren, P. (2009). Beyond Kappa: Estimating inter-rater agreement with nominal classifications. Journal of Modern Applied Statistical Methods, 8(1), 110-121. https://doi.org/10.22237/jmasm/1241136540

Birt, J., Stromberga, Z., Cowling, M. \& Moro, C. (2018). Mobile mixed reality for experiential learning and simulation in medical and health sciences education. Information, 9(2), 31. https://doi.org/10.3390/info9020031

Blaschke, L. M. (2012). Heutagogy and lifelong learning: A review of heutagogical practice and self-determined learning. The International Review of Research in Open and Distributed Learning, 13(1), 56-71. https://doi. org/10.19173/irrodl.v13i1.1076

Bulagang, A. F. \& Baharum, A. (2019). Mobile-augmented reality framework for students self-centred learning in higher education institutions. In R. Alfred, Y. Lim, A. A. A. Ibrahim \& P. Anthony (Eds.), Lecture Notes in Electrical Engineering (Vol. 481, pp. 87-96). Springer. https://doi.org/10.1007/978981-13-2622-6_9

Cárdenas-Robledo, L. A. \& Peña-Ayala, A. (2018). Ubiquitous learning: A systematic review. Telematics and Informatics, 35(5), 1097-1132. https://doi. org/10.1016/j.tele.2018.01.009

Carnie, F. (2017). Alternative Approaches to Education: A Guide for Teachers and Parents (Second edition). Taylor \& Francis. 
Casagranda, M., Colazzo, L., Molinari, A., Tomasini, S. \& Villa, N. (2011). Lifelong learning implementations in virtual communities: Formal and informal approaches and their impact on learners. 2011 IEEE Global Engineering Education Conference (Educon) (pp. 1061-1068). IEEE. https://doi.org/10.1109/ EDUCON.2011.5773279

Chang, C.-Y., Lai, C.-L. \& Hwang, G.-J. (2018). Trends and research issues of mobile learning studies in nursing education: A review of academic publications from 1971 to 2016. Computers \& Education, 116, 28-48. https:// doi.org/10.1016/j.compedu.2017.09.001

Chen, C.-H. \& Hwang, G.-J. (2017). Effects of the team competition-based ubiquitous gaming approach on students' interactive patterns, collective efficacy and awareness of collaboration and communication. Educational Technology and Society, 20(1), 87-98. https://www.researchgate.net/ publication/312220654_Effects_of_the_Team_Competition-Based_Ubi quitous_Gaming_Approach_on_Students\%27_Interactive_Patterns_Collec tive_Efficacy_and_Awareness_of_Collaboration_and_Communication

Chou, P.-N. \& Feng, S.-T. (2019). Using a tablet computer application to advance high school students' laboratory learning experiences: A focus on electrical engineering education. Sustainability, 11(2), 381. https://doi.org/10.3390/ su11020381

Chung, C.-J., Hwang, G.-J. \& Lai, C.-L. (2019). A review of experimental mobile learning research in 2010-2016 based on the activity theory framework. Computers \& Education, 129, 1-13. https://doi.org/10.1016/j.compe du. 2018.10 .010

Collins, A. \& Halverson, R. (2010). The second educational revolution: Rethinking education in the age of technology. Journal of Computer Assisted Learning, 26(1), 18-27. https://doi.org/10.1111/j.1365-2729.2009.00339.x

Comas-Quinn, A., Mardomingo, R. \& Valentine, C. (2009). Mobile blogs in language learning: Making the most of informal and situated learning opportunities. ReCALL, 21(01), 96. https://doi.org/10.1017/S0958344009000032

Drigas, A. \& Angelidakis, P. (2017). Mobile applications within education: An overview of application paradigms in specific categories. International Journal of Interactive Mobile Technologies (IJIM), 11(4), 17. https://doi. org/10.3991/ijim.v11i4.6589

Efstathiou, I., Kyza, E. A. \& Georgiou, Y. (2018). An inquiry-based augmented reality mobile learning approach to fostering primary school students' historical reasoning in non-formal settings. Interactive Learning Environments, 26(1), 22-41. https://doi.org/10.1080/10494820.2016.1276076

Fatima, J. K., Ghandforoush, P., Khan, M. \& Mascio, R. D. (2019). Mobile learning adoption for tourism education in a developing country. Current Issues in Tourism, 22(4), 420-427. https://doi.org/10.1080/13683500.2018.1434135

Fetaji, B. \& Fetaji, M. (2011). Analyses and review of M-learning feasibility, trends, advantages and drawbacks in the past decade (2000-2010). Proceedings of the European Computing Conference, ECC'11 (pp. 474-479). WSEAS.

Fombona, J., Pascual-Sevillana, Á. \& González-Videgaray, M. (2017). M-learning and augmented reality: A review of the scientific literature on the WoS repository. Comunicar, 25(52), 63-72. https://doi.org/10.3916/C52-2017-06 
Garrett, B. M., Jackson, C. \& Wilson, B. (2015). Augmented reality m-learning to enhance nursing skills acquisition in the clinical skills laboratory. Interactive Technology and Smart Education, 12(4), 298-314. https://doi.org/10.1108/ ITSE-05-2015-0013

Hakak, S., Noor, N. F. M., Ayub, M. N., Affal, H., Hussin, N., Ahmed, E. \& Imran, M. (2019). Cloud-assisted gamification for education and learning: Recent advances and challenges. Computers \& Electrical Engineering, 74, 22-34. https://doi.org/10.1016/j.compeleceng.2019.01.002

Hervis, E. E. (2017). La educación en América Latina: desarrollo y perspectivas. Revista Electrónica Actualidades Investigativas en Educación, 17(2), 1-23. https://doi.org/10.15517/aie.v17i1.28147

Horn, M. B. \& Fisher, J. F. (2017). New faces of blended learning. Educational Leadership, 74(6), 59-63. http://www.ascd.org/publications/educationalleadership/mar17/vol74/num06/New-Faces-of-Blended-Learning.aspx

Huang, S.-H., Wu, T.-T., Chen, H.-R., Yang, P.-C. \& Huang, Y.-M. (2012). Mathematics assisted instruction system of $\mathrm{m} / \mathrm{u}$-Learning environment. Proceedings 2012 17th IEEE International Conference on Wireless, Mobile and Ubiquitous Technology in Education, WMUTE 2012 (pp. 301-305). https://doi. org/10.1109/WMUTE.2012.72

Huber, B. (2013). Homogenizing the curriculum: Manufacturing the standardized student. Workplace: A Journal for Academic Labor, (8), 104-107. https:// doi.org/10.14288/workplace.v0i8.184619

Hussain, A. B., Hussein, R. M., Dahr, J. M. \& Neamah, M. A. (2015). Existing trends in usability evaluation method (UEM) for M-learning apps: A systimatic review. ARPN Journal of Engineering and Applied Sciences, 10(15), 6649-6653.

Juneau, K. R. (2012). A reflection on the history of educational technology and evolving pedagogies. In S. Wang \& T. Hartsell (Eds.), Technology Integration and Foundations for Effective Leadership: (pp. 18-41). IGI Global. https:// doi.org/10.4018/978-1-4666-2656-0

Kaliisa, R. \& Picard, M. (2017). A systematic review on mobile learning in higher education: The African perspective. Turkish Online Journal of Educational Technology, 16(1), 1-18. https://eric.ed.gov/?id=EJ1124918

Kalpana, G., Kumar, P. V., Aljawarneh, S. \& Krishnaiah, R. V. (2018). Shifted adaption homomorphism encryption for mobile and cloud learning. Computers \& Electrical Engineering, 65, 178-195. https://doi.org/10.1016/j.com peleceng.2017.05.022

Kukulska-Hulme, A. \& Traxler, J. (Eds.). (2005). Mobile learning: A handbook for educators and trainers. Routledge. https://doi.org/10.4324/9780203003428

Kurubacak, G. \& Altinpulluk, H. (Eds.). (2017). Mobile Technologies and Augmented Reality in Open Education. Advisory Board. https://doi. org/10.4018/978-1-5225-2110-5

Liss, J. M. (2013). Creative destruction and globalization: The rise of massive standardized education platforms. Globalizations, 10(4), 557-570. https://doi. org/10.1080/14747731.2013.806741 
Mallya, K. R. \& Dhas, C. S. G. (2016). Secure learning in the mobile cloud. 2016 IEEE International Conference on Advances in Computer Applications (Icaca), 125-130. IEEE. https://doi.org/10.1109/ICACA.2016.7887936

Melles, G., Winfree, T. \& Graham, P. (2019). Collaborative design of mobile interfaces for vocational building and construction education. In A. Chakrabarti (Ed.), Research into Design for a Connected World (Vol. 134, pp. 641-651). Springer. https://doi.org/10.1007/978-981-13-5974-3_56

Muñoz-Miralles, R., Ortega-González, R., Batalla-Martínez, C., López-Morón, M. R., Manresa, J. M. \& Torán-Monserrat, P. (2014). Acceso y uso de nuevas tecnologías entre los jóvenes de educación secundaria, implicaciones en salud. Estudio JOITIC. Atención Primaria, 46(2), 77-88. https://doi.org/10.1016/j. aprim.2013.06.001

Murphy, A., Farley, H., Lane, M., Hafeez-Baig, A. \& Carter, B. (2014). Mobile learning anytime, anywhere: What are our students doing? Australasian Journal of Information Systems, 18(3). https://doi.org/10.3127/ajis. v18i3.1098

Muyinda, P. B. (2007). MLearning: Pedagogical, technical and organisational hypes and realities. Campus-Wide Information Systems, 24(2), 97-104. https://doi.org/10.1108/10650740710742709

Nikou, S. A. \& Economides, A. A. (2018). Mobile-based micro-learning and assessment: Impact on learning performance and motivation of high school students. Journal of Computer Assisted Learning, 34(3), 269-278. https:// doi.org/10.1111/jcal.12240

Okoli, C. \& Schabram, K. (2010). A guide to conducting a systematic literature review of information systems research. Sprouts: Working Papers on Information Systems, 26(10), 1-51. https://papers.ssrn.com/sol3/papers.cfm? abstract id $=1954824$

Organero, M. M., Yndurain, E. \& Kloos, C. D. (2009). M-learning: Personalized and pervasive education anytime, anywhere and for everybody. In J. J. Pazos-Arias, C. Delgado-Kloos \& M. Lopez-Nores (Eds.), Personalization of Interactive Multimedia Services: A Reseach and Development Perspective (pp. 221-245). https://www.scopus.com/inward/record. uri?eid=2-s2.0-84896155641\&partnerlD $=40 \& \mathrm{md5}=7$ aef08cd6faa5964e 80df19351392b62

Organización de las Naciones Unidas para la Educación, la Ciencia y la Cultura (Unesco). (2013). Directrices para las políticas de aprendizaje móvil. Author. http://www.unesco.org/new/fileadmin/MULTIMEDIA/HQ/ED/ICT/ images/114_13_ED_UNESCO_Policy_Guidelines_for_Mobile_Learning_S.pdf

Pedro, L. F. M. G., Barbosa, C. M. M. de O. \& Santos, C. M. das N. (2018). A critical review of mobile learning integration in formal educational contexts. International Journal of Educational Technology in Higher Education, 15(1), 1-15. https://doi.org/10.1186/s41239-018-0091-4

Pimmer, C., Brühlmann, F., Odetola, T. D., Oluwasola, D. O., Dipeolu, O. \& Ajuwon, A. J. (2019). Facilitating professional mobile learning communities with instant messaging. Computers \& Education, 128, 102-112. https://doi. org/10.1016/j.compedu.2018.09.005 
Prensky, M. (2008). Turning on the lights. Educational Leadership, 65(6), 40-45. http://www.ascd.org/publications/educational-leadership/mar08/vol65/ num06/Turning-On-the-Lights.aspx

Punset, E. (2011). El sistema educativo es anacrónico: entrevista de Eduardo Punset a Sir Ken Robinson. http://www.educaciofisica.com/223_sistema_educativo_anacronico_entrevista_a_ken_robinson_03_2011.pdf

Rienzo, P. D. (2014). Recognition and validation of non formal and informal learning: Lifelong learning and university in the Italian context. Journal of Adult and Continuing Education, 20(1), 39-52. https://doi.org/10.7227/ JACE.20.1.3

Robinson, K. (2017). Out of our Minds: The Power of Being Creative (Third edition). John Wiley.

Rodríguez, M. N. (2013). El m-learning y los usos de tablets y celulares en el aula de clase, ¿distractores o dinamizadores del aprendizaje? Praxis Investigativa ReDIE, 5(8), 94-100. https://www.google.com/url?sa=t\&rct= $j \& q=\& e s r c=s \&$ source $=$ web\&cd $=\&$ ved $=2$ ahUKEwivgrDg0s7uAhUrpFk KHYswBUEQFjAAegQIARAC\&url=https\%3A\%2F\%2Fdialnet.unirioja.es\%2F descarga\%2Farticulo\%2F6552335. pdf\&usg=AOvVaw2c-XIQAAnDKdkp PY1oPQiN

Romero, M., Usart, M. \& Ott, M. (2015). Can Serious Games Contribute to Developing and Sustaining 21st Century Skills? Games and Culture, 10(2), 148-177. https://doi.org/10.1177/1555412014548919

Şendurur, E., Efendioğlu, E., Çalişkan, N. Y., Boldbaatar, N., Kandin, E. \& Namazli, $S$. (2017). The M-learning experience of language learners in informal settings. Proceedings of the 13th International Conference on Mobile Learning 2017, ML 2017, 119-123. IADIS. https://www.scopus.com/inward/record. uri?eid $=2-$ s2.0-85032492305\&partnerlD $=40 \&$ md5 $=92$ b9ca120f3598 c8ba6081cee90aaf36

Seyedmonir, B. (2013). The one world school house: Education reimagined. Distance Education, 34(3), 399-405. https://doi.org/10.1080/01587919.2013 .835777

Shadiev, R., Hwang, W.-Y., Huang, Y.-M. \& Liu, T.-Y. (2018). Facilitating application of language skills in authentic environments with a mobile learning system. Journal of Computer Assisted Learning, 34(1), 42-52. https://doi. org/10.1111/jcal.12212

Shippee, M. \& Keengwe, J. (2014). mLearning: Anytime, anywhere learning transcending the boundaries of the educational box. Education and Information Technologies, 19(1), 103-113. https://doi.org/10.1007/s10639-012-9211-2

Slotta, J. D., Quintana, R. M. \& Moher, T. (2018). Collective inquiry in communities of learners. In F. Fischer, C. E. Hmelo-Silver, S. R. Goldman \& P. Reimann (Eds.), International Handbook of the Learning Sciences (1st ed., pp. 308-317). Routledge. https://doi.org/10.4324/9781315617572

Stevenson, M., Hedberg, J., Highfield, K. \& Diao, M. (2015). Visualizing solutions: Apps as cognitive stepping-stones in the learning process. Electronic Journal of E-Learning, 13(5), 366-379. https://www.researchgate.net/ publication/283057149_Visualizing_Solutions_Apps_as_Cognitive_Step ping-Stones_in_the_Learning_Process 
Stoyanova, M., Tuparova, D. \& Samardzhiev, K. (2017). Gamification in 11th grade mathematics lessons: One possible interactive approach. In M. E. Auer, D. Guralnick \& J. Uhomoibhi (Eds.), Interactive Collaborative Learning (Vol. 545, pp. 41-53). Springer. https://doi.org/10.1007/978-3-319-50340-0_4

Sunkel, G. (2006). Las tecnologías de la información y la comunicación (TIC) en la educación en América Latina: una exploración de indicadores. Naciones Unidas / Cepal. https://repositorio.cepal.org/bitstream/handle/11362/6133/ S0600907_es.pdf?sequence $=1$

Toh, S. Y., Abdullah, N. S., Miskon, S., Rahman, A. A. \& Habil, H. (2015). Personal knowledge management in m-Learning: A systematic literature review. Advanced Science Letters, 21(6), 1910-1914. https://doi.org/10.1166/ asl.2015.6158

Tosi, D. \& Bisiani, R. (2007). A platform to support anytime, anywhere, just-forme m-learning. In Proceeding of the 7th IEEE International Conference on Advanced Learning Technologies, ICALT 2007 (pp. 114-116). IEEE. https:// doi.org/10.1109/ICALT.2007.32

Trifonova, A. \& Ronchetti, M. (2006, July 5-7). Mobile learning: Is anytime + anywhere = always online? Proceedings Sixth International Conference on Advanced Learning Technologies, ICALT 2006 (pp. 702-706). https:// www.scopus.com/inward/record.uri?eid=2-s2.0-34247104126\&partner $I D=40 \& m d 5=81$ e3d279cb32f73baf875560b06609c6

Van Laar, E., Van Deursen, A. J. A. M., Van Dijk, J. A. G. M. \& De Haan, J. (2017). The relation between 21st-century skills and digital skills: A systematic literature review. Computers in Human Behavior, 72, 577-588. https://doi. org/10.1016/j.chb.2017.03.010

Vanbaelen, R., Harrison, J. \& Van Dongen, G. (2014, October 13-15). Lifelong learning in a Fourth World setting. In 2014 IEEE International Professional Communication Conference (IPCC) (pp. 1-9). IEEE. https://doi.org/10.1109/ IPCC.2014.7020347

Vidmar, T. (2014). New dimensions of understanding of lifelong learning from Antiquity to Comenius. Review of European Studies, 6(3), 91-101. https:// doi.org/10.5539/res.v6n3p91

Waliński, J. T. (2014). Implementing linguistic landscape investigations with m-learning for intercultural competence development. International Journal of Mobile and Blended Learning, 6(2), 15-25. https://doi.org/10.4018/ ijmbl.2014040102

Wang, X., Zhao, M., Huang, C., Zhu, J. \& Tang, Y. (2019). Predicting students' mood level using multi-feature fusion joint sentiment-topic model in mobile learning. In Y. Sun, T. Lu, X. Xie, L. Gao \& H. Fan (Eds.), Computer Supported Cooperative Work and Social Computing (Vol. 917, pp. 316-330). Springer. https://doi.org/10.1007/978-981-13-3044-5_23

Wegerif, R. \& Major, L. (2018). Buber, educational technology, and the expansion of dialogic space. Al \& Society, 34, 109-199. https://doi.org/10.1007/ s00146-018-0828-6

Willemse, J. J., Jooste, K. \& Bozalek, V. (2019). Experiences of undergraduate nursing students on an authentic mobile learning enactment at a higher education institution in South Africa. Nurse Education Today, 74, 69-75. https://doi.org/10.1016/j.nedt.2018.11.021 
Wu, Y.-L. (2016). Gamification design: A comparison of four m-learning courses. Innovations in Education and Teaching International, 1-9. https://doi.org/1 $0.1080 / 14703297.2016 .1250662$

Zaragoza, M. G., Kim, H.-K. \& Hwang, H. J. (2019). E-learning adaptation and mobile learning for education. In R. Lee (Ed.), Applied Computing and Information Technology (Vol. 788, pp. 27-36). Springer. https://doi. org/10.1007/978-3-319-98370-7_3

Zempoalteca-Durán, B., Barragán-López, J. F., González-Martínez, J. \& Guzmán-Flores, T. (2017). Formación en TIC y competencia digital en la docencia en instituciones públicas de educación superior. Apertura, 9(1), 80-96. https://doi.org/10.32870/ap.v9n1.922

Zurita, G. \& Baloian, N. (2012). Context, patterns and geo-collaboration to support situated learning. In J. Bravo, D. López-de-Ipiña \& F. Moya (Eds.), Ubiquitous Computing and Ambient Intelligence (Vol. 7656, pp. 503-511). Springer. https://doi.org/10.1007/978-3-642-35377-2_69 